\title{
MEXICAN SCIENTISTS IN THE MAKING OF NUTRITIONAL AND NuClEAR DiPLOMACY IN THE FIRST HALF OF THE TWENTIETH CENTURY
}

\author{
Adriana Minor; \\ Universidad Nacional Autónoma de México (UNAM); \\ adrianaminorg@ciencias.unam.mx \\ Joel V argas-Dominguez; \\ Facultad de Ciencias, (UNAM); \\ joelvargas@ciencias.unam.mx
}

\begin{abstract}
This article focuses on scientist-diplomats that are the scientists who serve as national representatives and consultants for discussions on scientific and technical issues in international organizations. We examine two exemplary cases of Mexican scientist-diplomats: Francisco de Paula Miranda and Manuel Sandoval Vallarta, experts in nutrition and atomic energy, respectively. We discuss especially bow they became involved as experts in the international arena, and we analyse the feedback process of construction of their scientific and diplomatic authority. Furthermore, we consider the interaction of interests (disciplinary, professional, local, and global) that they represented and negotiated.
\end{abstract}

Keywords: Experts, nutrition, nuclear diplomacy, scientist-diplomats, Mexico, Manuel Sandoval Vallarta, Francisco de Paula Miranda

\section{INTRODUCTION}

In this paper, we focus on the way scientists were formally involved in diplomacy, a trend that was boosted in the twentieth century with the establishment of several international organizations. 1 The

${ }^{1}$ Ronald E. Doel, "Scientists as Policymakers, Advisors, and Intelligence Agents: Linking Contemporary Diplomatic History with the History of Contemporary Science," in The Historiography of Contemporary Science and Technology, ed. Thomas Söderqvist (Amsterdam: Harwood Academic Publishers, 1997), 215-44; John Krige and Kai-Henrik Barth, "Introduction: Science, Technology, and International Afairs," Osiris 2006, 21: 1-21. 
scientist-diplomats, as we call them, contributed to interweave scientific, political, and social problems, which were considered internationally relevant in these organizations. ${ }^{2}$ We are not suggesting that scientists became involved in diplomacy and policymaking merely in the twentieth century, but we recognize that the internationalist movements influenced by two World Wars increased their institutional participation as fundamental and even autonomous actors in global issues. As Schot and Kaiser have suggested, in that period experts developed specific skills in managing international and transnational relations through "stable expert networks" in what has been called "technocratic internationalism.",3

The analysis of science in diplomacy has focused mostly on international organizations; instead we propose a biographical approach to analyse how scientists became experts along with the emergence of these forums. This is crucial for the comprehension of the complex interactions between science and state-power that are expressed through the way scientists acquired political agency in international discussions and in the definition of public policies. ${ }^{4}$ This perspective also aims at promoting the convergence of international relations and science studies. As other scholars have noticed, the study of experts can foster constructively the combination of findings and analytical tools originating in these two fields. ${ }^{5}$

\footnotetext{
2 The terms 'scientist diplomat' or 'scientific diplomat' have been used with similar meaning as we refer to in this paper. See, for instance: Martin Sherwood and Michael Kenward, "Scientific Attachment," New Scientist (London, 1973); Alexis De Greiff, "Abdus Salam : A Migrant Scientist in Post-Imperial Times," Economic and Political Weekly, 2006; Martin Theaker, "The Rise of the Scientist-Diplomat within British Atomic Energy, 1945-1955," in Scientist's Expertise as Performance, eds. Joris Vandendriessche, Evert Peeters, and Kaat Wils (London: Routledge, 2015), 115-34.

3 W. Kaiser W and J. Schot, Writing the Rules for Europe: Experts, Cartels, and International Organizations (Hampshire: Palgrave Macmillan, 2014), 5-6.

${ }^{4}$ Sheila Jasanoff identifies this as one of the most important contributions of the study of experts: Sheila Jasanoff, "Breaking the Waves in Science Studies: Comment on H. M. Collins and Robert Evans, "The Third Wave of Science Studies," Social Studies of Science 2003, 33 (3): 389-400.

${ }^{5}$ For a general account of the perspectives from international relations and science studies on the role of experts, see: Christian Bueger, "From Expert Communities to Epistemic Arrangements: Situating Expertise in International Relations," in The Global Politics of Science and Technology - Vol. 1, eds. Maximilian Mayer, Mariana Carpes, and Ruth Knoblich (Heidelberg: Springer, 2014), 39-54.
} 
The inclusion of scientists in diplomacy was not a uniform process in every national context. ${ }^{6}$ In this paper, we analyse two cases of scientists who acted as representatives of Mexico in international organizations: Manuel Sandoval Vallarta (1899-1977), and Francisco de Paula Miranda (1890-1950). Both stood out locally and internationally because of their specialised knowledge in their respective disciplines: physics and nutrition. Their expertise matched with the need of the Mexican government to represent and defend national interests in the international organizations created in the 1940s. We examine the role these scientist-diplomats performed as experts in scientific concerns and the specificities they brought to the international arena as Mexican scientists and representatives of their nation. Furthermore, each of our cases highlights different aspects of the role of scientist-diplomats. In the case of Miranda, we provide a broad perspective of the overall shaping process of his role as scientist-diplomat through local and international forums, whereas for Sandoval Vallarta we present a more specific analysis of the scientist-diplomat's performative ability to manage a complex of interests in the context of representing a nation with a strong and distinguished tradition in foreign affairs.

Diplomacy in the first half of the twentieth century changed in important ways. It was affected by the impact of both World Wars I and II, as well as technological innovations, the consideration of new concerns in the diplomatic agenda, and the inclusion of new actors in the foreign services. 7 The creation of international organizations, such as the League of Nations (LN; 1920-1946), the United Nations (UN; 1942), and its multiple specialized technical agencies, introduced changes in the way traditional diplomacy was performed. In this setting, diplomatic efforts supposed that international peace would be guaranteed through these new organizations that promoted the values of democracy, commerce, economic independence and, as this article suggests, scientific rationality, into a common regulatory framework that could provide rational solutions to international challenges, in our cases, hunger and the handling of atomic energy.

Since the late nineteenth century, scientific knowledge was promoted as a crucial instrument for solving international issues, a

${ }^{6}$ The case of atomic energy in the UK illustrates this point: Theaker, "The Rise of the Scientist-Diplomat."

7 Ralph Blessing, "A Changing Diplomatic World," in A Companion to International History, 1900-2001, ed. Gordon Martel (Oxford: Blackwell Publishing, 2007), 6577.

HoST - Journal of History of Science and Technology 11, pp. 34-56 DOI 10.1515/host-2017-0003 
recognition that strengthened and expanded with the creation of international organizations in the twentieth century.8 As Speich Chassé has argued, scientific expertise was gradually incorporated into diplomacy in the interwar period, and it quickly gained a prominent position that it has kept since. ${ }^{9}$ Then, scientists were considered as relevant actors to evaluate concerns of international politics. Many of them had no previous experience in the diplomatic service; they were newcomers in diplomacy, but nonetheless their proposals were deemed to have global repercussions. At the same time, the scientist-diplomats maintained and reinforced their position as active and influential researchers in their local scientific institutions. They also represented a professional collective with a particular role in the international arena: "scientist-lobbyists," as Jachertz has called them, ${ }^{10}$ who combined their professional interests with their international activity. Furthermore, their scientific expertise could add values of objectivity, universalism, and truth to international decisions. From this point of view, they contributed to the justification of the geopolitics of hegemonic powers conducted through international organizations. ${ }^{11}$ The role of scientist-diplomats expanded the spaces in which science became politically influential at local and international level. These new actors enlisted themselves with the call of governments that required scientists to be able to manage those new "weapons of peace."

Although the inclusion of scientists in the framework of diplomacy increased after the World War II, as we will see, their participation was defined as part of a former internationalist trend.12 In this respect, Krige and Barth have stressed: ${ }^{13}$

8 Blessing, "A Changing Diplomatic World," 66-67.

9 Speich Chassé, Daniel, "Technical Internationalism and Economic Development at the Founding Moment of the UN System," in International organizations and development, 1945-1990, eds. Marc Frey, Sönke Kunkel and Corinna R. Unger, (London: Palgrave Macmillan, 2014), 23-45, on p. 30.

${ }^{10}$ Jachertz, Ruth, "To Keep Food Out of Politics': The UN Food and Agriculture Organization, 1945-1965," in International Organizations and Development, 1945-1990, eds. Marc Frey, et al., (London: Palgrave Macmillan, 2014), 75-100, on p. 75.

11 Krige, John, "Atoms for Peace, Scientific Internationalism, and Scientific Intelligence," Osiris 21 (2006): 161-81.

12 Somsen, Geert, "A History of Universalism: Conceptions of the Internationality of Science from the Enlightenment to the Cold War," Minerva 2008, 46 (3): 361-79.; Chassé, "Technical Internationalism."

13 Krige and Barth, "Introduction," p. 3. 
Prior to WWII, scientists themselves 'informally' conducted much of that international effort, as individuals or through their national and international scientific societies. After the war (and sometimes building on foundations that had been prepared for a while), the international bonds between scientists and the collaborative practices that expressed them, provided a platform for the integration of science and scientists into foreign affairs. Now they were essential not only for the development and security of the nation but also in its dealings with other states, in its efforts to project and consolidate its power in the international domain and to build a stable world order.

The scientist-diplomats analysed in this article had the specialised knowledge and scientific credentials demanded to perform as experts in the international arena, but this role was also endorsed by local scientific communities and political circles that provided them with recognition and validation in diplomatic settings, thus acquiring an agency that was not merely as technical advisors. Meanwhile their role as scientist-diplomats contributed to reinforce their local and international prestige, Miranda and Sandoval Vallarta also profited from such prestige as feedback to maintain their consideration as the most recognised "Mexican experts" in their corresponding fields of expertise. The fact that nutritional science and nuclear physics had few specialists in Mexico-where both disciplines were still in a process of consolidation-increased their political significance. Furthermore, the international pressure, and the sense of emergency in the fields of food and atomic energy positioned these scientists in a relevant role of policy-making both in Mexico and abroad. In that sense, their roles as scientistdiplomats meant a privileged platform to promote their perspectives about how to conduct and organize science nationally and to orient policies in that respect.

This kind of expert is not only a provider of specialized knowledge, thus of scientific rationality, but also intertwines disciplinary, international, and national interests into diplomacy. ${ }^{14}$ The scientistdiplomat introduced a more formal role for scientists in

\footnotetext{
14 This perspective is taking into account in: De Greiff, "Abdus Salam." HoST - Journal of History of Science and Technology 11, pp. 34-56 DOI 10.1515/host-2017-0003
} 
international relations, emerging as a particular kind of expert, as members of an institutionalised representation of a nation sustained on the values of science. While there existed technical experts summoned by the government as consultants, or acting politically through organizations not necessarily linked with the government, what we call scientist-diplomats conveyed a commitment with the representation and defence of national interests, according to the dictates of government (that is the case of Sandoval Vallarta), or occasionally defining those dictates with the agreement of government (just as Miranda did). Some authors have pinpointed that experts were especially independent in their handling of international affairs, prompted by their expertise and the promotion of technocracy around the world. ${ }^{15}$ However, in the case of scientist-diplomats, this freedom based on specialised knowledge was tied to the interests of the nation and the government these experts represented.

In this paper, first we explore the career of Francisco de Paula Miranda as an expert in nutrition, in Mexico and representing Mexico abroad, and the way he could connect his research interests and international research agendas; second, we review the specific case of Manuel Sandoval Vallarta's participation in the creation of the UN's Atomic Energy Commission. The latter highlights how scientist-diplomats combine and adjust their technical advice with national concerns, and in particular the relevance of national foreign affairs traditions (such as the Mexican one and its distinctive defence of sovereignty) in their performance. Finally, we draw some conclusions that emphasize the different scientific and political networks that sustain the practice of science diplomacy.

\section{Becoming an EXPERT: Francisco de PaUla Miranda AND MEXICAN NUTRITIONAL SCIENCE}

The Interwar period brought into focus the problem of feeding the population. The "imperfect nutrition" of the "working classes" could lead to political unrest, and may possibly lead to more wars. ${ }^{16}$ Nutrition experts' role was reinforced by international organisations such as the LN, the International Labour Office, the International Institute of Agriculture in Rome, and the Rockefeller Foundation

\footnotetext{
${ }^{15}$ Kaiser and Schot, "Writing the Rules for Europe."

16 David F. Smith, "Nutrition Science and the Two World Wars," in Nutrition in Britain. Science, Scientists and Politics in the Twentieth Century, ed. David F. Smith (London: Routledge, 1997), 150.
} 
(RF), which conformed nutrition scientists' advice to create more accurate and comprehensible nutritional research. ${ }^{17}$

International organisations and scientists became "major agents" in "the genesis of scientific knowledge, political and commercial uses [of diet and nutrition], and social and political practices."18 The LN produced a report with nutritional guidelines that established "on a scientific basis the causes of poverty and disease,"19 and had to be followed by its members. ${ }^{20}$ This report was considered one of the founding papers of social nutrition science: "nutrition attentive to the social meanings of food and to poverty as the cause of malnutrition," an approach that was common to several international developments in nutrition in the 1930s and 1940s. ${ }^{21}$ Science was the answer to the problem of nutrition and hunger, and experts on nutrition were the ones that had to implement this approach.

The guidelines were incorporated in 1943 through the UN Conference on Food and Agriculture (UNCFA) that took place in Hot Springs, Virginia, USA. This meeting was the precursor of the Food and Agriculture Organization of the UN (FAO). The UNCFA declared its belief "that the goal of freedom from want of food, suitable and adequate for the health and strength of all peoples" could be achieved. Such optimistic belief was sustained by the increasing role of experts in the specialized commissions of that conference. The "findings and recommendations" of the experts assembled there had to be studied and adopted by the governments they represented, including countries from Latin America, Africa and Asia. ${ }^{22}$

17 Josep L. Barona,"Nutrition and Health. The International Context During the Inter-War Crisis," Social History of Medicine 2008, 21, (1): 87-105, on p. 88.

18 Josep L. Barona, The Problem of Nutrition (Brussels: Peter Lang, 2010), 139.

19 Paul Weindling, "Introduction: Constructing International Health between the Wars," in International Health Organizations and Movements, 19181939 (Cambridge: Cambridge University Press, 1995), 4.

${ }^{20}$ League of Nations and International Institute of Agriculture, The Problem of Nutrition, 4 vols., A 12, A 12 (a)-(c) 1936 II B. Geneva 1936. A comprehensive analysis of the report and the impact in Europe of these meetings can be found in Barona, "Nutrition and Health"; Barona, The Problem of Nutrition.

${ }^{21}$ James Vernon, Hunger, a Modern History (Cambridge, MA: The Belknap Press, 2007), 119-120.

22 United Nations Conference on Food and Agriculture, Final Act of the HoST - Journal of History of Science and Technology 11, pp. 34-56 DOI 10.1515/host-2017-0003 
A Mexican Delegation attended the UNCFA, and Francisco de Paula Miranda, a Mexican physiologist, was selected by his country as one of its technical advisors. Later on, he became the Mexican representative at several FAO advisory committees. ${ }^{23}$ Miranda's international career did not emerge in the post-war period, but it was a result of the internationalism that had characterised the medical profession since the beginning of the twentieth century. This was related to the increased concern about public health, and the measures needed to be taken by nations to stop epidemics and improve commercial exchanges. ${ }^{24}$

Figure 1. Francisco de Paula Miranda, courtesy of the Library and Archive of the Academia Nacional de Medicina de México

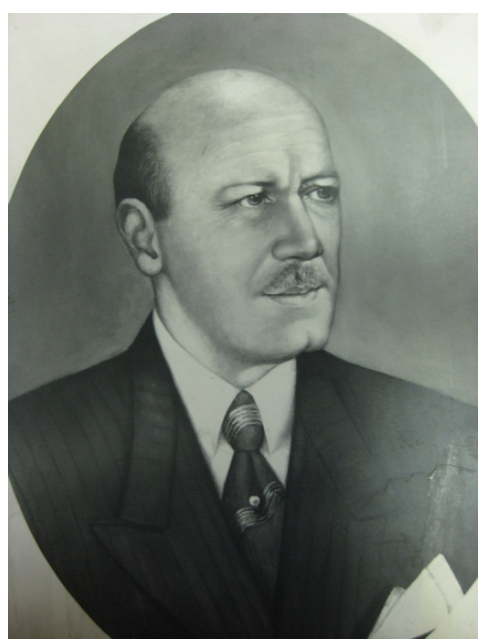

Miranda was a health officer who was sent to New Orleans in 1921, when he was commissioned by the Mexican Ministry of Health (Secretaría de Salud y Asistencia / SSA), to translate the US Sanitary Laws into Spanish. Then, he also profited from studying the

United Nations Conference on Food and Agriculture, Hot Springs, Virginia, United States of America, 18th May-3rd June 1943 (London: H. M. Stationery off., 1943), 13.

23 Several technical advisors attended the conference. This research focuses only in one case (nutrition), of the several approaches to food problems that were tackled in the interwar period. The agricultural approach is the one followed by Harwood, Jonathan. "Peasant Friendly Plant Breeding and the Early Years of the Green Revolution in Mexico." Agricultural History 2009, 83, (3): 384-410.

${ }^{24}$ Cueto, Marcos, Theodore Brown, and Elizabeth Fee, "El proceso de creación de la Organización Mundial de la Salud y la Guerra Fría," Apuntes 2011, 38 (69): 129-156; Palmer, Steven and Claudia Agostoni, "Introduction: Landscapes of Latin American Health, 1870-1970," Canadian Journal of Latin American and Caribbean Studies 2010, 35, (69): 5-18. 
measures adopted by the US to prevent the appearance and spread of tropical diseases resulting from sea trade or travel. ${ }^{25}$ Then, Miranda, an expert endocrinologist, became an enthusiast of organisations like the Red Cross and the RF, which showed the "advantages of internationalism." 26 In the 1930s, Miranda was chosen to be the head of the International Exchange Section of the SSA, a position that allowed him to attend several international conferences as the Mexican Health delegate. He was also acquainted with the newest medical literature, which he selected and translated to Spanish, and distributed among colleagues at the Ministry. ${ }^{27}$ In the 1930s, he published articles on endocrinology and biochemistry, and was elected director of the National Academy of Medicine, the most prestigious medical association in Mexico. ${ }^{28}$ Then, his initial interests in endocrinological disorders like diabetes moved to the field of physiology of nutrition. Miranda was familiar with the social nutrition approach and the publications of the LN. In this context, he became interested in the study of the nutritional and physiological conditions of the Mexican population.

The interest of Miranda in social nutrition grew in the middle of the 1930s when he became the head of the Comisión Nacional de Alimentación (CNA) (National Food Commission) created by the Mexican president Lázaro Cárdenas with the objective of knowing and improving the living standards of the population, by providing an optimum diet, ${ }^{29}$ not just the minimum, one of the key arguments of understanding hunger as a social problem. ${ }^{30}$ This Commission promoted the creation of an Institute specialized in nutrition that

${ }^{25}$ Francisco de Paula Miranda, "Sanidad marítima. Estudio de las leyes de sanidad marítima de los Estados Unidos," Boletín del Departamento de Salubridad Pública. Segunda Época 1, no. 1-6 (Mayo 1921); Gabriel M. Malda, "Informe que rinde el Jefe del Departamento de Salubridad, la noche del 2 de junio de 1921 con motivo de la instalación solemne de las oficinas en el nuevo local (Reforma 93)," Boletin del Departamento de Salubridad Pública. Segunda Época 1, no. 7-12 (1921): 321.

${ }^{26}$ Miranda, " Sanidad marítima."

27 Francisco de Paula Miranda, "Sección de Intercambio. Informe correspondiente al año de 1931," Salubridad 2, no. 1-2-3-4 (1931).

${ }_{28}$ Ana Cecilia Rodríguez de Romo, Gabriela Castañeda López, and Rita Robles Valencia, Protagonistas de la medicina científica mexicana, 1800-2006 (México, D.F.: Plaza y Valdés, 2008).

29 Secretaría de Asistencia Pública, La obra de los Comedores Nacionales, Archivo Histórico de la Secretaría de Salubridad y Asistencia (AHSSA), Fondo BP, Sección Dirección, Serie SubSecretaría, Caja 16, vol. 5, 1941.

${ }^{30}$ For more about the characteristics of social nutrition, see Vernon, "Hunger," p. 136.

HoST - Journal of History of Science and Technology 11, pp. 34-56 DOI 10.1515/host-2017-0003 
would use science to find out the social and economic causes of malnutrition, as well as a school to train more people into this field. ${ }^{31}$

As head of the CNA, Miranda and the International Health Division of the RF coordinated local nutritional surveys by the end of the 1930s, a collaboration that would last for most part of the 1940s. ${ }^{32}$ The surveys provided information about the food consumption habits of the diverse population groups that inhabited Mexico, focusing on peasants, indigenous populations and urbanpoor dwellers. The latter would be reframed as "models" of the Mexican population, undernourished and susceptible to improvement through social engineering. ${ }^{33}$ The findings were part of the evidence of the social nutrition approach taking place in Mexico that Miranda brought to the UNCFA at Hot Springs. ${ }^{34}$

Miranda explained at the UNCFA that poverty was "the predominant cause of malnutrition" in Mexico, so his government was taking important measures to attack the "problem of nutrition," such as improving local food consumption through social welfare programs, and creating specialised educational programmes on nutrition and hygiene. He also proposed that all those policies had to be replicated at the international context as part of the objectives of the UNCFA. The Mexican Delegation statement, written by Miranda, emphasised the new nutritional research conducted at the new Instituto Nacional de Nutriología

31 Aurea Procel, Memorandum que la profesora Aurea Procel presenta al C. Presidente de la República, acerca del establecimiento en México, por cooperación internacional, de un Instituto encargado de investigar lo relativo a la alimentación popular (Archivo General de la Nación, Fondo Manuel Ávila Camacho, 103202; México, 1941).

32 The RF had had an important role in the spread of scientific medicine in the first half of the twentieth century, and Mexico had hosted RF health initiatives since the 1920s. See Anne-Emanuelle Birn, Marriage of Convenience: Rockefeller International Health and Revolutionary Mexico, Rochester Studies in Medical History, (Rochester: University of Rochester Press, 2006).

33 The way these "models" of population were constructed in the midst of a eugenical setting is explored in Joel Vargas-Domínguez, Metabolismo y nutrición en el México posrevolucionario: engenesia y clasificación de la población Mexicana entre 1927 y 1943. Ph.D. dissertation, Universidad Nacional Autónoma de México. (Ciudad de México: México, 2017).

34 Letter from William D. Robinson to John A. Ferrell, May 10, 1943, RAC, RF, RG 1.1, S 323, B 12, F 81. The results were later published as a pioneering work: Wilbur D. Robinson, George C. Payne, and José Calvo de la Torre, "A Study of the Nutritional Status of a Population Group in Mexico City," Journal of the American Dietetic Association 1944: 20. 
(INNu), created in 1943 and directed by Miranda. ${ }^{35}$ The social nutrition approach that permeated at the meeting was incorporated into the Final Act of the UNCFA, stating that "the first cause of hunger and malnutrition is poverty." 36 The scientific basis of the recommendations was supposed to be applicable to all members of $\mathrm{UN}$, through the local nutrition organizations. As Weindling has stated, "the universalism of science found natural affinity with internationalist ideals" 37 and, Miranda, as head of the INNu, became the natural representative to the subsequent international meetings. This movement adhered to the recommendations of the UNCFA that local experts needed "to exchange views and to make proposals for any national and international action necessary to facilitate the progress of their work." 38

Miranda was invited to participate in several expert committees on nutrition during the 1940s, both as an expert and as the Mexican representative. ${ }^{39}$ He promoted in Mexico the application of the FAO dietary standards or allowances, based upon scientific evidence, and therefore "universal," but only achievable depending on the available local foodstuffs, and his research was oriented towards the evaluation of the food habits of the population. ${ }^{40} \mathrm{At}$ the INNu, he consolidated a network of researchers thanks to the financial aid given by the RF, the Kellogg Foundation, and the Massachusetts Institute of Technology (MIT), which produced among other investigations, the first comprehensive compositional list of typical Mexican foodstuffs, and an overview of the nutritional habits of several population groups. ${ }^{41}$

35 Prevalent causes and consequences of malnutrition in Mexico, in "United Nations Conference on Food and Agriculture Hot Springs Va. 1943”, Documents 1-352, 5 vols. (Hot Springs: 1943).

36 "Final Act of the United Nations Conference on Food and Agriculture," p. 13.

${ }^{37}$ Weindling, International Health Organizations," p. 4.

38 "Final Act of the United Nations Conference on Food and Agriculture," p. 27.

${ }^{39}$ Memo del Secretario Particular del Sec. de la SSA, el Lic. Andrés Serrra Rojas, a FPM director del INN, 27 de abril de 1944, AHSSA, Fondo SSA, Sección SPr, Caja 23, Exp. 1, 1944: 355; Recordatorio a Gustavo Baz para el acuerdo presidencial, 19 de julio de 1946, AHSSA, Fondo SSA, Sección SPr, Caja 13, Exp. 3 1943-1970: 56.

40 Miranda, Francisco de P. Plan de trabajo del Instituto Nacional de Nutriología, 1947 AHSSA, Fondo SSA, Caja 21 Expediente 2 1947-1953.

${ }^{41}$ René Cravioto B. et al., "Composition of Typical Mexican Foods," The Journal of nutrition 1945, 29 (5); R. O. Cravioto et al., "Nutritive Value of the Mexican Tortilla," Science 1945, 102 (2639); Richmond K. Anderson et HoST - Journal of History of Science and Technology 11, pp. 34-56 DOI 10.1515/host-2017-0003 
Miranda died in 1950, and the INNu lost with him part of the political connections he had created, and part of its financial stability. When it closed its doors in 1956, it was barely functioning as a laboratory to analyse the seeds produced by the Mexican Agriculture Program of the RF. ${ }^{42}$

Miranda's case illustrates the diverse array of social skills, academic and political factors that made him a nutrition expert. Miranda was recognized as an authoritative voice from Mexico in the international meetings he attended, but his expert advice was also relevant at the local level. However, he also entangled the global with the local approach; global recommendations had to be contextualized when practiced, and local experts on international committees presupposed the creation of universal standards which could and should be followed by everyone. These early years of the technical divisions of the UN, seems to follow the ideals of the interwar period of the use of science and diplomacy as instruments for peace, suggesting more continuations than ruptures from the Interwar period. ${ }^{43}$ The technical committees were just "the apex of a complex structure that brought into active association thousands of health workers worldwide." 44 Similar conditions prevailed in other UN technical agencies, as the following case of Sandoval Vallarta will show.

\section{MANAgINg NuClEAR DiplomaCY AMONG ATOMIC ENERgY CONCERNS, NATIONAL SOVEREIGNTY, AND SCIENTIFIC INTERNATIONALISM}

The previous section considers a panoramic view of the trajectory of a Mexican expert in nutrition, pointing out the mutual

al., "A Study of the Nutritional Status and Food Habits of Otomi Indians in the Mezquital Valley of Mexico," Am J Public Health 1946, 36; José Calvo de la Torre et al., "Nutritional Status of Economically Poor Families Fed in a Government-Operated Dining Room in Mexico City," Journal of the American Dietetic Association 1946, 22; Francisco de Paula Miranda, La alimentación en México, (México, D.F.: Instituto Nacional de Nutriología, 1947).

42 Nick Cullather, The Hungry World: America's Cold War Battle against Poverty in Asia (Cambridge MA: Harvard University Press, 2010).

43 As Miller has shown in: Miller, Clark, "An Effective Instrument of Peace": Scientific Cooperation as an Instrument of U.S. Foreign Policy, 1938-1950," Osiris 2006, 21: 133-160.

44 David Dubin, "The League of Nations Health Organization," in International Health Organizations and Movements, 1918-1939, ed. Paul Weindling (Cambridge: Cambridge University Press, 1995): 65. 
reinforcement of status from local to international back and forth. This section analyses the participation of a scientist-diplomat in a specific international meeting, in order to dig into the type of interactions of national interests, global geopolitics, and specialised knowledge that a scientist-diplomat had to balance and mediate with.

The creation of an international commission devoted to atomic energy had become an urgent task after the detonation of the atomic bombs in Japan in 1945. In this scenario, in December of that year a meeting was organized in Moscow by the Council of Foreign Ministers with representatives of the five permanent state members of the United Nations' Security Council: the United States of America (US), the United Kingdom (UK), China, France, and the Soviet Union (USSR). They proposed the creation of a commission for the international control and regulation of atomic energy, which would be subordinated to the Security Council (SC), as suggested by the US and UK representatives. ${ }^{45}$ Moreover, the resolutions taken by the commission would be subjected to the power of veto, following the USSR stance. 46

Consequently, the first meeting of the UN's General Assembly, which took place in London in January 1946, voted as its inaugural agreement the creation of the Atomic Energy Commission (AEC).47 The AEC would be in charge of the following issues: to regulate the international exchange of scientific information; to secure the use of atomic energy for pacific purposes; to eliminate nuclear weapons; and to secure peace through regular inspections for protecting other nations against violations of international agreements on the uses of atomic energy. The AEC would be constituted by representatives of the five state members of the SC, jointly with Canada, and the non-permanent state members elected then by the UN General Assembly (Australia, Brazil, Egypt, Mexico, the Netherlands, and Poland). ${ }^{48}$

${ }^{45}$ David Fischer, History of the International Atomic Energy Agency: The First Forty Years (Vienna: The Agency, 1997), p. 18.

46 The power of veto implied that each decision taken by the Security Council had to be approved by all the permanent state members and that it would be enough if one of those countries disagreed to block any proposal.

47 "Resolutions adopted on the reports of the first committee" document available in http://daccess-ddsny.un.org/doc/RESOLUTION/GEN/NR0/032/52/IMG/NR003252.pdf?Op enElement [accessed on 2 April, 2014].

48. Atomic Energy Commission, Official Records, Eighth meeting, December 17, 1946. Archivo Histórico Científico - Manuel Sandoval Vallarta [from now on: HoST - Journal of History of Science and Technology 11, pp. 34-56 DOI 10.1515/host-2017-0003 
This decision drove the Mexican government to select a representative for the AEC, which launched international discussion of one of the scientific topics that deserved more attention in diplomacy at that time and during the Cold War. Whereas other countries appointed diplomats or members of the army to head their delegations into the AEC, Mexico chose to select a scientist, following the recommendation presented by its Secretary of Foreign Affairs (Secretaría de Relaciones Exteriores; SRE) "[...] it would be convenient if the Mexican delegate [...] were a man of a high scientific level who, because of his discipline and activities, was able to understand all aspects of the problem and to speak with authority." ${ }_{49}$ By doing so, the Mexican diplomatic service opened a way to the official appointment of a scientist-diplomat, a man whose specialized knowledge gave him the authority to speak and defend the national interests.

In fact, the Mexican Foreign Service went through a process of professionalisation, redefinition, and enlargement favoured by the creation of post-war international organisations. ${ }^{50}$ For instance, during the celebration of the AEC meeting, the Mexican Foreign Secretary requested a physicist to occupy a permanent position associated with the representation of the country at the UN, an expert who would assist in issues of atomic energy. ${ }^{51}$ For the Mexican government the best understanding of atomic energy concerned the field of physics (although this topic crossed other disciplines, such as chemistry, medicine or engineering). That association demanded as never before the inclusion of a physicist among diplomatic delegations. Regarding the designation of the Mexican delegate at the AEC, the SRE expressed that having a physicist for this diplomatic mission was crucial. This was made clear when after the suggestion of appointing someone with experience in the Mexican diplomatic service, the SRE asserted that this alternative was "not really satisfactory" since the suggested diplomat lacked of "the technical knowledge, [...] and because of

AHC-MSV], section Institucional, subsection ONU, series Comisión de Energía Atómica, box 35, file 2 .

${ }^{49}$ Letter from the Secretary of Foreign Affairs, Francisco Castillo Nájera, to the Secretary of Public Education, February 2, 1946. Archivo Histórico "Genaro Estrada" de la Secretaría de Relaciones Exteriores [from now on: AHGESRE], III1285-1 (9a. Parte), 1946. - Comisión para el Control de la Energía Atómica.

50 Roberta Lajous Vargas, Las relaciones exteriores de México (1810-1910) (Ciudad de México: El Colegio de México, 2012), p. 240.

51 Letter from Pablo Campos Ortiz, on behalf of the Mexican ambassador Luis Padilla Nervo to Manuel Sandoval Vallarta, September 14th, 1946. AHGESRE, III-1285-1 (9a. Parte), 1946.-Comisión para el Control de la Energía Atómica. 
that his participation in the discussions [...] would not give the results for Mexico that are expected." ${ }_{52}$

At that time, physics research in Mexico was still in a process of consolidation. In fact, the need for physicists that national nuclear research demanded meant a fundamental impetus for that purpose. By then, the small community of physicists, configured around the first Mexican Institute of Physics at the Universidad Nacional Autónoma de México, was mainly focused on cosmic radiation and gravitation research. Notably, this community had a close relationship with physicists from the US, due to the intervention of Manuel Sandoval Vallarta, the first Mexican professional physicist whose scientific career was developed mostly in that country.53 After WWII, Sandoval Vallarta had just come back to Mexico, and the government decided to profit both from his expertise and his international contacts. ${ }^{54}$ In that sense, it is not surprising that the UN's Mexican representation suggested him as the AEC Mexican delegate, 55 and appointed him officially in April 1946.56

\footnotetext{
52 Memorandum for a presidential statement, May 17, 1946. AHGESRE, III-12851 (9a. Parte), 1946.

53 Adriana Minor, "Shaping 'Good Neighbor' Practices in Science: Mobility of Physics Instruments Between the United States and Mexico, 1932-1951" in Scientific Instruments in the History of Science: Studies in Transfers, Use and Preservation, eds. Marcus Granato and Marta Lourenço (Rio de Janeiro: MAST, 2014): 185-206.

54 For details on the conditions that took Sandoval Vallarta back to Mexico, see: Minor García, Adriana, "Manuel Sandoval Vallarta en la encrucijada entre Estados Unidos y México,” Ludus Vitalis 2015, XXIII, 43: 125-49.

55 Telegram from Rosenzweig Díaz to the Secretary of Foreign Affairs, January 31, 1946. AHGESRE, III-1285-1 (9a. Parte), 1946.

56 Letter from the subsecretary of Foreign Affairs, Manuel Tello, to the representative of Mexico in the UN's Security Council, Rafael de la Colina, April 24, 1946. AHGESRE, III-1285-1 (9a. Parte), 1946.

HoST - Journal of History of Science and Technology 11, pp. 34-56 DOI 10.1515/host-2017-0003
} 
Figure 2. Manuel Sandoval Vallarta. Official Photograph of the Atomic Energy Commission (June, 1946), Courtesy of the Archivo Histórico de la UNAM (Colección Universidad, CU-17824).

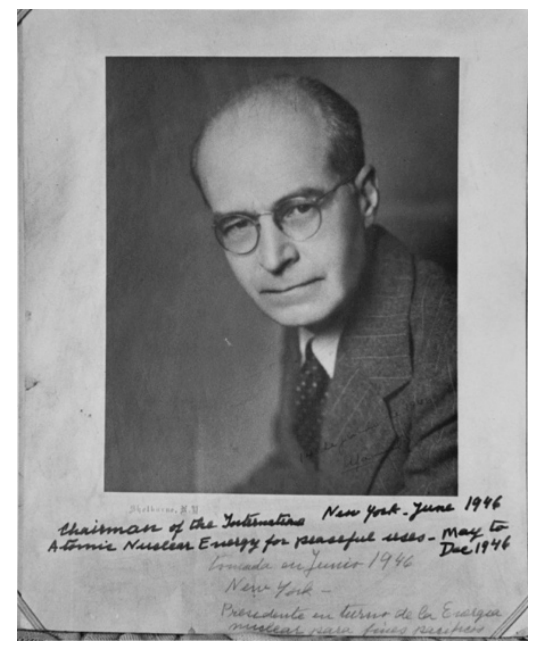

Sandoval Vallarta built and consolidated his scientific authority during his career in the US. ${ }^{57} \mathrm{He}$ was trained as a theoretical physicist at MIT, where he got a Ph.D. in 1924, and was an active professor in the Department of Physics until 1941. He was part of the first MIT generation specialising in quantum physics and he became a prominent scientist because of his theoretical research in cosmic rays. Certainly, Sandoval Vallarta had the theoretical knowledge about the subatomic world to understand the scientific and technical details about atomic energy. Though, to be precise, his research was not directly related to the wide range of topics, materials and instruments related to the area of atomic energy and its military or peaceful uses, such as nuclear weaponry, radioisotopes, radioactive materials, particle accelerators, or nuclear reactors.

In addition to his scientific credentials, Sandoval Vallarta built a close relationship to the Mexican government, gaining access to public appointments. Since his family had been relevant in Mexican political history, he continued this lineage by reaching an important role as an interlocutor mediating science and politics..$^{58}$ Actually, one

${ }^{57}$ Adriana Minor García, "Cruzar fronteras: Movilizaciones científicas y relaciones interamericanas en la trayectoria de Manuel Sandoval Vallarta (1917-1942)" (Ph.D. Thesis, Universidad Nacional Autónoma de México, 2016).

${ }^{58}$ For instance, his grandfather, Ignacio Vallarta, was an important liberal politician of the $1^{\text {th }}$ century who became Secretary of Foreign Affairs. Also, there were other diplomats in his family, such as the writer Alfonso Reyes. Roderic Ai Camp has shown how this kind of familiar history has contributed to create powerful elites in Mexico, see: Roderic Ai Camp, Mexico's Mandarins: Crafting a Power Elite for 
of the reasons he decided to return from the US to his native country was because of a proposal from the Mexican government to head a national organisation for the encouragement and coordination of scientific research. ${ }^{9}$ Thus he reconfigured his scientific career as a Mexican scientist after he had developed professionally in the US for twenty-five years. In that sense, his participation as a scientist-diplomat was part of this professional shift.

Furthermore, through this geographical and professional relocation Sandoval Vallarta continued with his previous performance on the uses of science in diplomacy. During WWII, he collaborated with the US government in the promotion of its Good Neighbor Policy through the exchange of scientific publications between Latin American and US scientists. ${ }^{60}$ In this manner, he had played a role as a kind of informal (US) scientific ambassador. After the war, his formal engagement in diplomacy was configured as a scientist expert in nuclear issues representing then the interests of the Mexican government.

According to the instructions the SRE gave to Sandoval Vallarta, the official position of Mexico in the AEC had to be consistent with the main national foreign policy principles, as well as the recommendations presented by the Economy Secretary and the Law Service. For the Mexican government, the major issue to defend was the property of natural resources. In fact, the nationalisation of radioactive deposits was the first reaction of the Mexican government after the detonation of nuclear bombs. ${ }^{61}$ The

the Twenty-First Century (Berkeley: University of California Press, 2002).

${ }^{59}$ Minor García, "Manuel Sandoval Vallarta en la encrucijada."

${ }^{60}$ Adriana Minor García, "Traducción e intercambios científicos entre Estados Unidos y Latinoamérica: El Comité Inter-Americano de Publicación Científica (1941-1949)," in Aproximaciones a lo local y lo global: América Latina en la bistoria de la ciencia contemporánea, eds. Gisela Mateos and Edna Suárez-Díaz (Ciudad de México: Centro de Estudios Filosóficos, Políticos y Sociales Vicente Lombardo Toledano, 2016), 183-214. The Good Neighbor Policy was a foreign policy implemented by the administration of the US president Franklin Delano Roosevelt (1933-1945), whose main objective was to improve the relationship with the governments of the Latin American countries based on the principles of non-intervention and mutual understanding, see for instance: Spellacy, Amy, "Mapping the Metaphor of the Good Neighbor: Geography, Globalism, and Pan-Americanism during the 1940s," American Studies 2006, 47, 2: 39-66; Darlene J. Sadlier, Americans All: Good Neighbor Cultural Diplomacy in World War II (Austin: University of Texas Press, 2012).

${ }^{61}$ Luz Fernanda Azuela and José Luis Talancón, Contracorriente: La bistoria de la energía nuclear en México, 1945-1995 (México D. F: Plaza y Valdes, 1999), p.33; Cabral, Regis, "The Mexican Reactions to the Hiroshima and Nagasaki Tragedies of 1945.," Quipu 1987, 4, 1: 81-118.

HoST - Journal of History of Science and Technology 11, pp. 34-56 DOI 10.1515/host-2017-0003 
nationalisation of natural resources had been a historical milestone of post-revolutionary Mexico, as when President Lázaro Cárdenas nationalised the oil industry in 1938, which had involved diplomatic disagreement with other powerful nations, especially with the US. Thus, for Mexico securing the property of natural resources was historically significant.

During WWII, the Mexican and US governments improved their international relations. ${ }^{62}$ In that period, the Mexican government followed a non-intervention foreign policy, maintaining the political independence that characterized its participation in international forums during the Cold War. ${ }^{63}$ Mexico forged an ambivalent position that waved between its non-intervention policy and its alliances with the US, which was reflected in the position represented by Sandoval Vallarta at the AEC. His diplomatic discourse there included both claims for collaboration and for sovereignty: "the propositions presented by [the US representative] are acceptable to Mexico, although the issue about the property of uranium minerals would need a careful and separate study yet."64

The AEC first meeting took place between June and December of 1946. Mexico belonged to this Commission only during the time of its effective membership into the UN's Security Council, that was only for one year. Sandoval Vallarta stood out as the only head delegate who was a scientist. The rest were politicians, army officials, or professionals of the diplomatic service in their respective countries. 65 Of course, each delegation had technical advisers, among them well-known nuclear physicists such as the UK delegate James Chadwick, and the French delegates Frédéric Joliot-Curie and Francis Perrin. ${ }^{6}$ For Mexico, the group that

\footnotetext{
62 Josefina Zoraida Vázquez and Lorenzo Meyer, México Frente a Estados Unidos: Un Ensayo Histórico, 1776-2000, (México, D.F.: Fondo de Cultura Económica, 2006 (1982)): 181-190.

${ }^{63}$ Friedrich Katz, "La guerra fría en América Latina" in Espejos de la Guerra Fría: México, America Central y el Caribe, ed. Daniela Spencer (México D.F.: CIESAS, 2004): 11-28.

${ }^{64}$ Manuel Sandoval Vallarta, Report by the Mexican delegate in the Atomic Energy Commission, July 10, 1946. AHGESRE, III-1285-1 (9a. Parte), 1946.

65 The complete list of delegates included: Bernard Baruch (US), Alexander Cadogan (UK), Quo Tai-Chi (China), François de Rose (Francia), Andrei Gromyko (URSS), Paul Hasluck (Australia), Col. Alvaro Alberto (Brazil), Col. Mohamed Bey Khalifa (Egypt), Eelco Van Kleffens (The Netherlands), Oskar Ryszard Lange (Poland), and General Andrew McNaughton (Canada). Atomic Energy Commission, Official Records, Eighth meeting, December 17, 1946, AHCMSV, section Institucional, subsection ONU, series Comisión de Energía Atómica, box 35, file 2 .

${ }^{66}$ List of the Delegates to the United Nations Commission on Atomic Energy, 2
} 
accompanied the delegation included an army official, a physicist, and an engineer. ${ }^{67}$ The combination of scientists, politicians, and army officials reveals the formation of the hybrid space of negotiations and exchanges that characterised nuclear diplomacy.

In general, the AEC discussion was centred on the international control of atomic energy, a plan presented by the US, called the Baruch Plan, and the rival Soviet proposal.68 The plan of the US consisted in the creation of an international organisation with capacity to determine and sanction the activities related to atomic energy that imply a risk to world security. Moreover, it proposed that the organisation would concentrate all the information about resources of atomic fuel. Furthermore, its decisions would not be subject to the Security Council veto. Instead, the USSR suggested organising first an international convention in which each country would inform about their nuclear armament and after that, they would compromise to destroy it. Only in that premise, would it be possible to create an international organisation for the regulation of atomic energy. For the Soviet government, it was essential that the AEC would maintain the power to veto.

Certainly, these two proposals dominated the work of the AEC, but as the Mexican position suggests, to consider that bipolar geopolitics was implied as the only force that drove discussions in this forum would be an oversimplification. The Mexican government, on the one hand, supported the position of the US regarding the elimination of the power of veto with regard to matters that belonged to the AEC. On the other hand, Mexico promoted the nationalisation of radioactive deposits. As pointed out by the Mexican delegate, "it was convened to establish the obligation in each country that possesses uranium deposits to nationalize them, just as Mexico and the United States have done, and to sell the products of these deposits to the [AEC]." ${ }_{9}$ Furthermore, the Mexican government agreed with the installation of AEC plants for the separation of uranium and thorium, but it

March, 1946. AHGESRE, III-1285-1 (9a. Parte), 1946.

67 They were: Gen. Manuel Cabrera Carrasquedo, physicist Carlos Graef Fernandez, and engineer Nabor Carrillo. Carrillo also attended the atomic bomb demonstration at Bikini Atoll. Graef was director of UNAM's Physics Institute, and Carrillo was coordinator of scientific research at the same university (he became its rector from 1953 to 1961). Graef, Carrillo and Sandoval Vallarta (all of them got their Ph.D. in US universities) would be members of the Mexican National Commission on Nuclear Energy, created in 1956.

68 Fischer, "History of the IAEA," 18-20.

${ }^{69}$ Manuel Sandoval Vallarta, Report by the Mexican delegate in the Atomic Energy Commission, July 10, 1946. AHGESRE, III-1285-1 (9a. Parte), 1946. HoST - Journal of History of Science and Technology 11, pp. 34-56 DOI 10.1515/host-2017-0003 
claimed in turn that each country had to receive an amount of the refined products, which were extracted from the national territory. Regarding mines and atomic energy facilities, the Mexican government proposed that inspections should be conducted not only by AEC officials, but also by local experts. ${ }^{70}$ The Mexican delegation clearly stated the property of natural resources, whatever they were, as a matter of an inalienable national principle, an issue that was at the core of the formation of post-revolutionary Mexico.

Since there was not an agreement resulting of this first AEC meeting, the impact of the Mexican position is not evident. But attending issues as those stated by the Mexican representation at the AEC, enables a more complete understanding of the manifold complex processes that shaped post-war nuclear diplomacy. Gabrielle Hecht has demonstrated the importance of thinking in terms of broader processes instead of only key moments of high bipolar politics about nuclear programs. ${ }^{71}$ Following a similar perspective, Jacques Hymans underlines the importance of Mexico in nuclear politics for its promotion of non-proliferation treaties in the 1960s that secured Latin America as a nuclear weapon free zone. ${ }^{72}$

It was neither in this meeting, nor in the two hundred that followed, that an international agreement was achieved, with the result that the AEC was suspended in 1949.73 It was not until 1957 that an agreement about the international regulation of atomic energy was reached. ${ }^{74}$ However, the AEC played an important role as a forum where crucial themes of the international agenda emerged, such as the political forces that came to prevail during the Cold War. Moreover, the distinction of peaceful uses of atomic energy that started then to be delineated, years later justified the US international scientific policy of Atoms for Peace. ${ }^{75}$

\footnotetext{
70 Letter from the Secretary of Foreign Affairs, Francisco Castillo Nájera, to Manuel Sandoval Vallarta, June 1, 1946. AHGESRE, III-1285-1 (9a. Parte), 1946. 71 See for instance: Maximilian Mayer, "Nuclear Ontologies, Technopolitics in Postcolonial Spaces, and the Cold War as a Transnacional History: An interview with Gabrielle Hecht" in The Global Politics of Science and Technology Vol. 1, eds. M. Mayer, et al., (Heidelberg: Springer, 2014), pp. 275-282, on p. 276.

72 Jacques Hymans, "The Dynamics of Nuclear Politics: Lessons from Latin America" in Routledge Handbook of Latin America in the World, eds. Jorge Domínguez y Ana Covarrubias (New York: Routledge, 2014): 362-375.

73 Fischer, "History of the LAEA," p. 20.

${ }^{74}$ Hecht, Gabrielle, "Negotiating Global Nuclearities: Apartheid, Decolonization, and the Cold War in the Making of the IAEA", Osiris 2006, 21, 1: 25-48.

75 Krige, "Atoms for Peace."
} 
Sandoval Vallarta's specialized knowledge was important for his recruitment as scientist-diplomat, but it was not decisive in terms of defining the position he defended during his participation in the AEC. Even in the Subcommittee of technical aspects of atomic energy, which supervised the scientific and technical feasibility of monitoring nuclear activities, Sandoval Vallarta and other members expressed the view that it was not possible to discuss scientific aspects of atomic energy independently of political issues. On the occasion that Mexico led the AEC meeting for some weeks, Sandoval Vallarta gave an inaugural discourse dedicated to the defence of internationalism in science and the free exchange of scientific information:

The future of pure scientific research is at stake [...] for without a satisfactory form of control of atomic energy there is a great danger that research leading to the discovery of scientific truths will eventually stop altogether; that the exchange of scientific information will be so seriously curtailed as to disrupt the international brotherhood of science; that scientists will devote their efforts to the invention of more deadly means of warfare and will work in segregated groups, each bent on securing for his respective nation the greatest possible advantage of war. ${ }^{76}$

These words reflect his concerns about the challenges for science in relation to the atomic energy discussions. Since 1945, Sandoval Vallarta sustained the notion that scientists had to assume their historical compromise and intervene in the definition of the uses of atomic energy, even from politics, to maintain the ideal of internationalism in science, as he tried by representing Mexico at the AEC. ${ }^{77}$ The role of Sandoval Vallarta as expert in issues of atomic energy, made him part of the main national committees in this scientific aspect, contributing to the strengthening of nuclear physics research. Whereas Sandoval Vallarta as a scientist-diplomat represented national interests according to the government's dictates, an advantageous position as such also set the pattern for opening direct political channels allowing the negotiation of

\footnotetext{
76 Atomic Energy Commission, Official Records, Eighth meeting, December 17, 1946, AHC-MSV, sección Institucional, subsección ONU, serie Comisión de Energía Atómica, box 35, file 2.

77 Luz Fernanda Azuela, "Manuel Sandoval Vallarta y la responsabilidad del hombre de ciencia," in Humanismo Mexicano del Siglo XX, Tomo I, ed. Alberto Saladino García (Toluca: UAEM, 2004): 453-471.

HoST - Journal of History of Science and Technology 11, pp. 34-56 DOI 10.1515/host-2017-0003
} 
governmental support for science, and the increase of technical, instrumental, institutional, and professional capacities.

\section{CONCLUDING REMARKS}

This paper exposes the journey followed by two Mexican scientists while positioning themselves as experts and national representatives in the international organizations created at the dawn of the Post-war period. The role of this kind of expert in international organisations, and the definition itself of these organisations suggests in principle a genuine interest of integrating approaches from different national scientific communities in resulting agreements. The participation of Mexican scientistdiplomats in international organisations for nutrition and atomic energy shows that, although the geopolitical world order and economic asymmetry guided most of the decisions of these technical agencies, they were validated by a collective (international) scientific rationality. What is more, despite the apparently low impact of the proposals put forward by Mexican scientistdiplomats, certainly their participation contributed to reinforce their privileges at national and international level.

Francisco de Paula Miranda and Manuel Sandoval Vallarta were scientists that emphasised international collaboration in their careers, an element that became an important feature to intervene in the shaping of scientific cooperation as an effective instrument for the maintenance of international peace. Both scientists had in common their strong connections with the US scientific community, being acquainted with its traditions and practices. This influenced their research and the local scientific institutions they created. Their strategy of scientific collaboration kept feeding their international projection and conferred to them a distinguished status in their local scientific communities.

Miranda, and Sandoval Vallarta were pioneers in their respective disciplines in Mexico. The Mexican government took advantage of their expertise by recruiting them as national representatives in their diplomatic delegations in international meetings. Their commitment with the promotion of scientific internationalism and their local and international networks, made them ideal to participate in diplomacy. Both became scientist-diplomats, whose authority was not based solely on their specialized knowledge, but also on the international networks of knowledge and the political alliances they created along their career path. That diversity of sources of legitimation was also present in the commitments they 
defended, which converged in their belief in science as a weapon of peace.

An important current in the study of experts in Latin America has focused on those technocrats who, particularly from the 1960s, encouraged social, political, and economic development initiatives. This article expands the understanding of scientists as experts that have also contributed to delineate public policies in this region. Furthermore, scientists have also been absent from Mexican diplomatic history, but this article illustrates the importance of paying attention to their interventions in international settings. More studies are required to get deeper into the relation of science and diplomacy in this historical field. Finally, this article exemplifies the interest of studying scientist-diplomats by promoting further interaction between the history of international relations and science studies.

\section{ACKNOWLEDGEMENTS}

A first version of this paper was discussed in the colloquium "Expertos: Actores y espacios de legitimación y acción social," that took place in Mexico in April 28-29, 2014, with the support of the Graduate Programme in Philosophy of Science, UNAM. We want to thank all the participants in this meeting. Publishing expenses of this article were paid in the context of the project UID/HIS/00286/2013. 